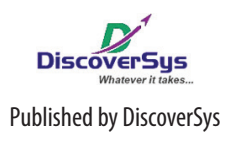

\section{Association between husband support and compliance with post-cryotherapy requirements among mothers in Tabanan District, Bali}

\author{
Gede Ngurah Upadana, ${ }^{1 *}$ Anak Agung Sagung Sawitri, ${ }^{2}$ \\ I Nyoman Mangku Karmaya ${ }^{3}$
}

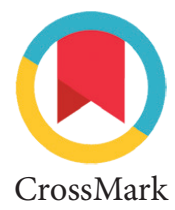

CrossMark

\title{
ABSTRACT
}

Background and purpose: Cervical cancer is a major global health problem for women, with most of cases occurring in developing countries. Visual inspection with acetic acid (VIA) is one method for screening precancerous cervical lesions which can then be followed up with cryotherapy. The success of cryotherapy is influenced by many factors including maternal compliance to meet the clinical requirements after cryotherapy. This study aims to determine the association between husband's support and mother's compliance with post-cryotherapy requirements.

Methods: A cross-sectional study was conducted on 142 mothers with positive VIA test results and had received cryotherapy in six Tabanan public health centers (PHCs) consisting of four PHCs in urban areas and two PHCs in rural areas. All mothers who underwent cryotherapy during 2017 were selected as samples. Data were collected through face-to-face interviews in each respondent's home using a questionnaire. The information collected was four post-cryotherapy requirements consisting of sexual abstinence, on schedule follow-up examinations, compliance to the recommended antibiotic use, not using topical vaginal medication and husband's support. Husband's support measured by 11 questions consisted of psychological, social and environmental support. Bivariate analysis was performed with chi-square and multivariate analysis with logistic regression.

Results: This study shows that only $39.4 \%$ of respondents were compliant to meet the four post cryotherapy requirements. As many as $32.4 \%$ of mothers had sex within 4 weeks after cryotherapy and $40.1 \%$ did not have the follow up examinations on schedule. Husband's support was significantly associated with maternal compliance in the form of asking about respondent's health condition with $A 0 R=6.658$ (95\%Cl: 1.794-24.702) and not asking for sex with $A 0 R=4.151$ (95\%Cl: 1.491-11.556).

Conclusion: Mother's compliance with the four requirements after cryotherapy remains low and the husband's support has a role in increasing maternal compliance. Education on post cryotherapy requirements needs to be improved particularly in regards to the role of the husband.
${ }^{1}$ Tabanan District Health Office, ${ }^{2}$ Department of Public Health and Preventive Medicine, Faculty of Medicine, Udayana University, ${ }^{3}$ Department of Anatomy, Facuty of Medicine, Udayana University

${ }^{*}$ Correspondence to: Gede Ngurah Upadana, Tabanan District Health Office, gedengurahupadana@gmail.com

Keywords: Visual inspection with acetic acid, compliance, cryotherapy, husband support

Cite This Article: Upadana, G.N., Sawitri, A.A.S., Karmaya, I.N.M. 2019. Association between husband support and compliance with postcryotherapy requirements among mothers in Tabanan District, Bali. Public Health and Preventive Medicine Archive 7(2): 148-155. D0I:10.15562/ phpma.v7i2.226

\section{INTRODUCTION}

Cervical cancer is one of the main global health problems in women, and is the second largest cause of death after breast cancer. ${ }^{1,2}$ The World Health Organization estimated that the number of cervical cancer cases in Indonesia in 2014 was 20,928 and ranked second after breast cancer with as many as 48,998 cases. $^{3}$ Data of The Indonesian Ministry of Health on the cumulative results of early cervical cancer detection activities in 2007-2016 shows Bali Province ranked $17^{\text {th }}$ in Indonesia, with 12,653 positive VIA cases and 254 (2\%) women suspected of cervical cancer. ${ }^{4}$ Results of early detection of cervical precancers in all districts in Bali Province in 2016 found 1,167 (19.8\%) women with positive VIA results from 5,901 examined. The highest number of mothers examined during 2016 was in Tabanan with 3,229 mothers and 477 (6.8\%) were found to be positive. ${ }^{5}$
Currently cervical cancer can be treated with a program called "see and treat" which is done through gynecological examination in the form of cervical observation after wiping acetic acid solution, known as visual inspection with acetic acid (VIA) examination. Those with positive VIA results or pre-cancerous lesions then proceed with cryotherapy treatment. ${ }^{6}$ Cryotherapy has been proven to be a cost effective destructive therapy for the treatment of an early stage cervical dysplasia so that it is used as a standard of treatment. ${ }^{7}$ A study in Jakarta reports that the results of evaluations with VIA six months after cryotherapy show a success rate of $90.7 \% .^{8}$ Cryotherapy can also inhibit progression of low squamous grade (LSIL) in high grade squamous lesion (HSIL) and in cervical cancer. ${ }^{9}$ Other studies have also shown that cryotherapy is effective to prevent cervical intraepithelial neoplasia (CIN) 
with cure rates of $81.4 \%$ for women with CIN 1; $71.4 \%$ for CIN 2 and $68.0 \%$ for CIN $3 .^{10}$

The success of cryotherapy is determined by several factors, namely the patient must be followed up at least three times, antibiotics must be taken as recommended, not using topical vaginal medication and not having sex for four weeks after cryotherapy. ${ }^{11,12}$ These requirements highly need the role of the husbands particularly for not having sex for four weeks.

Tabanan District in Bali Province has been implementing a "see and treat" program since 2011, and it was reported that mothers who had cervical dysplasia were $15.24 \%$ in 2011 and 6.8\% in 2016. Those who had cervical dysplasia received cryotherapy directly on the same day. ${ }^{13}$ Our preliminary study among ten women who had cryotherapy in four public health centres (PHCs) in Tabanan shows that they had difficulty in complying with the post cryotherapy requirements especially sexual abstinence for four weeks, because this requires support from their husband. In addition, four out of ten mothers did not have follow up examinations as recommended by health workers. Studies on maternal compliance to these requirements have not been widely published in Indonesia. This study was conducted to determine the association between compliance of mothers in following the requirements as recommended, with the support from their husbands.

\section{METHODS}

The study used an analytic cross-sectional design, and was carried out in 6 out of 20 PHCs in Tabanan District. All six PHCs, which are four in urban areas and two in rural, were selected as the study locations. The six PHCs were selected purposively with the consideration of the number of positive VIA cases and to represent urban and rural areas. The subjects (respondents) of the study were 142 married mothers who had positive VIA results and received cryotherapy at the six selected PHCs. The sample size was calculated with a $95 \%$ confidence level, $80 \%$ power and the proportion of mothers who came for follow up visit at Tabanan District was $24 \%$. Assuming this proportion (24\%) was those who did not have husband support, and if the noncompliant mothers decrease to $5 \%$ when they have husband support, the minimum required number of sample is 142 mothers with positive VIA. Data collection was conducted from May to August 2018 with face-to-face interviews in each respondent's home by enumerators who had been previously trained. Data on the characteristics of health providers were obtained from the PHCs.
Data collected consisted of socio-demographic characteristics of respondents, characteristics of health providers, maternal compliance with the four post-cryotherapy requirements and the roles of health providers and husband's support. Characteristics of respondents included education, number of children, residence, age, occupation, number of VIA examinations, frequency of VIA examinations with positive results and post-cryotherapy clinical symptoms. The health provider's characteristics consisted of age, length of working experience, employment status and length of time providing information to mothers after cryotherapy. Compliance of the mother to the four post-cryotherapy requirements consisted of sexual abstinence for four weeks, compliance to the recommended antibiotic use, on schedule three times follow up examinations and not using a topical vaginal medication. Mothers were categorized as "compliant" if they comply with all the four requirements and categorized as "non-compliant" if they do not comply one of those requirements. Types of husband's support measured with 11 questions include the 6 questions of psychological support (knowing his wife conducting cryotherapy, accompanying his wife during the follow up examinations, paying attention to his wife, asking about cryotherapy result, reminding about medication schedule, suggesting for reducing daily activities or resting), 3 questions of social support (helping to do daily tasks, giving extra money for vitamins and transportation) and 2 questions of environmental support (not smoking and not asking for sex). ${ }^{14}$

Data were analyzed with bivariate and multivariate approaches. Bivariate analysis using the chi square test was performed to identify the association between husband support and other variables with mother's compliance. All variables with $\mathrm{p}<0.25$ were included in the multviariate model by using logistic regression to determine factors related to maternal compliance.

This study has been approved by the Ethics Committee of the Faculty of Medicine, Udayana University/Sanglah General Hospital on April 2, 2018.

\section{RESULTS}

Table 1 shows that most respondents were over 34 years old $(63.4 \%)$, worked $(77.5 \%)$, had high school education and above (51.4\%) and had less than three children (77.5\%). Respondents' husbands were mostly over 35 years old $(76.8 \%)$, private employees (32.4\%) and educated above junior high (56.3\%). Most mothers carried out VIA examinations 1 to 2 times, and only a small proportion had 
Table 1 Characteristics of the respondents and their husband

\begin{tabular}{|c|c|c|}
\hline Respondent and husband characteristics & $\mathbf{n}$ & $\%$ \\
\hline \multicolumn{3}{|l|}{ Age (years) } \\
\hline$<25$ & 9 & 6.3 \\
\hline $25-34$ & 43 & 30.3 \\
\hline$>34$ & 90 & 63.4 \\
\hline \multicolumn{3}{|l|}{ Employment status } \\
\hline Unemployed & 32 & 22.5 \\
\hline Employed & 110 & 77.5 \\
\hline \multicolumn{3}{|l|}{ Education } \\
\hline$\geq$ Senior high school & 73 & 51.4 \\
\hline$<$ Senior high school & 69 & 48.6 \\
\hline \multicolumn{3}{|l|}{ Number of children } \\
\hline$\geq 3$ & 32 & 22.5 \\
\hline$<3$ & 110 & 77.5 \\
\hline \multicolumn{3}{|l|}{ Residence } \\
\hline Urban & 71 & 50.0 \\
\hline Rural & 71 & 50.0 \\
\hline \multicolumn{3}{|l|}{ Frequency of VIA examinations (time) } \\
\hline 1 & 57 & 40.1 \\
\hline 2 & 59 & 41.5 \\
\hline 3 & 24 & 16.9 \\
\hline$\geq 4$ & 2 & 1.4 \\
\hline \multicolumn{3}{|l|}{$\begin{array}{l}\text { Frequency of VIA tests with positive results } \\
\text { (time) }\end{array}$} \\
\hline 1 & 127 & 89.4 \\
\hline 2 & 14 & 9.9 \\
\hline 3 & 1 & 0.7 \\
\hline \multicolumn{3}{|l|}{ Age of husband (years) } \\
\hline $20-24$ & 4 & 2.8 \\
\hline $25-34$ & 29 & 20.4 \\
\hline $35-55$ & 109 & 76.8 \\
\hline \multicolumn{3}{|l|}{ Husband's employment } \\
\hline Government employees & 6 & 4.2 \\
\hline Private employees & 46 & 32.4 \\
\hline Sales & 26 & 18.3 \\
\hline Driver & 6 & 4.2 \\
\hline Laborers & 38 & 26.8 \\
\hline Other & 20 & 14.1 \\
\hline \multicolumn{3}{|l|}{ Husband's education } \\
\hline$\geq$ Senior high school & 80 & 56.3 \\
\hline$<$ Senior high school & 62 & 43.7 \\
\hline Total & 142 & 100.0 \\
\hline
\end{tabular}

carried out VIA tests up to three times or more. Most respondents (89.4\%) had experienced a positive VIA once, but there were a small proportion of respondents $(0.7 \%)$ had experienced a positive VIA up to three times.

Table 2 shows overall respondent compliance with the proportion of $39.4 \%$. Respondents who were not compliant in terms of abstaining from sex for 4 weeks after cryotherapy amounted to $32.4 \%$, comply with the recommended antibiotic use $(31.7 \%)$ and on schedule follow-up examinations (40.1\%).

Table 3 presents the results of a bivariate analysis between the variables of respondent characteristics, characteristics of health workers and husband support with maternal compliance with four post-cryotherapy requirements. Variables found significantly associated with the mothers' compliance were the characteristics of the health providers and the husband's support.

Characteristics of health providers that are significantly related include the length of health information provision, while those which have $\mathrm{p}<0.25$ are the length of working experience, employment status and age. Types of husband support which significantly associated with mothers' compliance include accompanying his wife during the follow up examinations, asking about the results of cryotherapy, reminding wife to take medication, asking about wife's health conditions, giving money for transportation, not smoking and not asking for sex. Type of husband's support which has $p<0.25$ is giving money to buy supplementary food and vitamins.

Table 4 shows that the variables associated with maternal compliance to implement the four requirements after cryotherapy were mothers' employment $(\mathrm{AOR}=3.750$; 95\%CI: 1.273-11.049; $\mathrm{p}=0.02$ ), the husband asked about wife's health condition $\quad(\mathrm{AOR}=6.658 ; \quad 95 \% \mathrm{CI}: \quad 1.794-24.702$; $\mathrm{p}<0.01)$ and asked for sex $(\mathrm{AOR}=4.151 ; 95 \% \mathrm{CI}$ : $1.491-11.556 ; \mathrm{p}<0.01)$.

\section{DISCUSSION}

This study shows that maternal compliance with the four requirements after cryotherapy remains low (39.4\%) because if one of the conditions was not met, it was included in the non-compliance category. The low compliance occurs especially for three indicators, namely sex abstinence for four weeks after cryotherapy, on schedule follow-up examinations and compliance with the recommended antibiotic use. The only requirement that was met was not to use vaginal topical medication, because respondents were not currently using topical post-cryotherapy medication and only $2.1 \%$ said they used betel leaf concoctions.

Our study shows that the factors associated with the maternal compliance are mothers who do 
Table 2 Mothers' compliance with the four post-cryotherapy requirements

\begin{tabular}{lcc}
\hline Compliance & $\mathbf{n}$ & $\%$ \\
\hline Compliance with all four requirements & 56 & 39.4 \\
$\quad$ Compliant & 86 & 60.6 \\
Non-compliant & & \\
Sexual intercourse last 4 weeks & 46 & 32.4 \\
$\quad$ Yes & 96 & 67.6 \\
No & & \\
Follow-up examination & 85 & 59.9 \\
Yes & 57 & 40.1 \\
No & & \\
Comply with recommended antibiotic use & 97 & 68.3 \\
Yes & 45 & 31.7 \\
No & & 97.9 \\
Not using vaginal lubricant & 139 & 2.1 \\
Yes & 3 & 100.0 \\
No & 142 & \\
Total & & \\
\end{tabular}

Table 3 Association between maternal compliance with socio-demographic characteristics, characteristics of health providers and husbands' support

\begin{tabular}{|c|c|c|c|c|c|}
\hline \multirow[b]{2}{*}{ Characteristics } & \multicolumn{2}{|c|}{ Compliant } & \multicolumn{2}{|c|}{ Non-compliant } & \multirow[b]{2}{*}{$\mathbf{p}$} \\
\hline & $\mathbf{n}$ & $\%$ & $\mathbf{n}$ & $\%$ & \\
\hline \multicolumn{6}{|l|}{ Respondent characteristics } \\
\hline \multicolumn{6}{|l|}{ Education } \\
\hline Never go to school & 0 & 0 & 2 & 100 & 0.38 \\
\hline Elementary & 7 & 41.2 & 10 & 58.8 & \\
\hline Junior high & 19 & 38.0 & 31 & 62.0 & \\
\hline Senior high & 22 & 36.7 & 38 & 63.3 & \\
\hline University & 8 & 61.5 & 5 & 38.5 & \\
\hline Mean number of children & 1.98 & $0.64(\mathrm{SD})$ & 2.07 & $0.77(\mathrm{SD})$ & 0.49 \\
\hline \multicolumn{6}{|l|}{ Residence } \\
\hline Urban & 29 & 40.8 & 42 & 59.2 & 0.73 \\
\hline Village & 27 & 38.0 & 44 & 62.0 & \\
\hline Mean age of husband & 36.91 & $8.13(\mathrm{SD})$ & 36.52 & $7.41(\mathrm{SD})$ & 0.77 \\
\hline \multicolumn{6}{|l|}{ Employment } \\
\hline Employed & 40 & 36.4 & 70 & 63.6 & 0.17 \\
\hline Unemployed & 16 & 50.0 & 16 & 50.0 & \\
\hline Mean frequency of VIA examinations & 1.696 & $0.85(\mathrm{SD})$ & 1.872 & $0.74(\mathrm{SD})$ & 0.30 \\
\hline Mean frequency of VIA positive results & 1.07 & $0.25(\mathrm{SD})$ & 1.14 & $0.38(\mathrm{SD})$ & 0.27 \\
\hline \multicolumn{6}{|l|}{ Clinical symptoms } \\
\hline No & 41 & 39.8 & 62 & 60.2 & 0.88 \\
\hline Yes & 15 & 38.5 & 24 & 61.2 & \\
\hline \multicolumn{6}{|l|}{ Healthcare provider characteristics } \\
\hline \multicolumn{6}{|c|}{ Length of time providing information (minute) } \\
\hline$\geq 5$ minute & 21 & 29.6 & 50 & 70.4 & 0.02 \\
\hline$<5$ minutes & 35 & 49.3 & 36 & 50.7 & \\
\hline
\end{tabular}


Table 3 Continue

\begin{tabular}{|c|c|c|c|c|c|}
\hline \multirow[b]{2}{*}{ Characteristics } & \multicolumn{2}{|c|}{ Compliant } & \multicolumn{2}{|c|}{ Non-compliant } & \multirow[b]{2}{*}{$\mathbf{p}$} \\
\hline & $\mathbf{n}$ & $\%$ & $\mathbf{n}$ & $\%$ & \\
\hline \multicolumn{6}{|c|}{ Length working experiences (years) } \\
\hline$\geq 20$ & 31 & 45.6 & 37 & 54.4 & 0.15 \\
\hline$<20$ & 25 & 33.8 & 49 & 66.2 & \\
\hline \multicolumn{6}{|l|}{ Employment status } \\
\hline Government employee & 48 & 37.8 & 79 & 62.2 & 0.24 \\
\hline Non government employee & 8 & 53.3 & 7 & 46.7 & \\
\hline \multicolumn{6}{|l|}{ Age (years) } \\
\hline$\leq 35$ & 8 & 25.0 & 24 & 75.0 & 0.06 \\
\hline$>35$ & 48 & 3.6 & 62 & 56.4 & \\
\hline \multicolumn{6}{|l|}{ Husband's supports } \\
\hline \multicolumn{6}{|c|}{ Awaresness of cryotherapy participation } \\
\hline Yes & 56 & 39.4 & 86 & 60.6 & \\
\hline No & 0 & 0 & 0 & 0 & \\
\hline \multicolumn{6}{|c|}{ Accompanying to the follow-up examinations } \\
\hline Yes & 28 & 51.9 & 26 & 48.1 & 0.02 \\
\hline No & 28 & 31.8 & 60 & 68.2 & \\
\hline \multicolumn{6}{|l|}{ Asking about cryotherapy results } \\
\hline Yes & 48 & 48.5 & 51 & 51.5 & $<0.01$ \\
\hline No & 8 & 18.6 & 35 & 81.4 & \\
\hline \multicolumn{6}{|l|}{ Reminding wife to take medicine } \\
\hline Yes & 37 & 52.9 & 33 & 47.1 & $<0.01$ \\
\hline No & 19 & 26.4 & 53 & 73.6 & \\
\hline \multicolumn{6}{|c|}{ Asking about wife's health condition } \\
\hline Yes & 46 & 56.8 & 35 & 43.2 & $<0.01$ \\
\hline No & 10 & 16.4 & 51 & 83.6 & \\
\hline \multicolumn{6}{|l|}{ Encouraging bed rest } \\
\hline Yes & 20 & 52.6 & 18 & 47.4 & 0.52 \\
\hline No & 36 & 34.6 & 68 & 65.4 & \\
\hline \multicolumn{6}{|l|}{ Assisting with housework } \\
\hline Yes & 18 & 46.2 & 21 & 53.8 & 0.31 \\
\hline No & 38 & 36.9 & 65 & 63.1 & \\
\hline \multicolumn{6}{|l|}{ Providing transportation money } \\
\hline Yes & 43 & 51.2 & 41 & 48.8 & $<0.01$ \\
\hline No & 13 & 22.4 & 45 & 77.6 & \\
\hline \multicolumn{6}{|c|}{ Providing money for food supplements and vitamins } \\
\hline Yes & 26 & 45.6 & 31 & 54.4 & 0.22 \\
\hline No & 30 & 35.3 & 55 & 64.7 & \\
\hline \multicolumn{6}{|l|}{ Smoking } \\
\hline Yes & 27 & 30.3 & 62 & 69.7 & $<0.01$ \\
\hline No & 29 & 54.7 & 24 & 45.3 & \\
\hline \multicolumn{6}{|l|}{ Asking for sex } \\
\hline Yes & 18 & 22.5 & 62 & 77.5 & $<0.01$ \\
\hline No & 38 & 61.3 & 24 & 38.7 & \\
\hline
\end{tabular}


Table 4 Association between husband's support and maternal compliance with the four post-cryotherapy requirements

\begin{tabular}{|c|c|c|c|c|}
\hline \multirow[b]{2}{*}{ Variables } & \multirow[b]{2}{*}{ AOR } & \multicolumn{2}{|c|}{$95 \% \mathrm{Cl}$} & \multirow[b]{2}{*}{$\mathbf{p}$} \\
\hline & & Lower & Upper & \\
\hline \multicolumn{5}{|l|}{ Mothers' employment } \\
\hline Employed & 1 (Ref) & & & \\
\hline Unemployed & 3.750 & 1.273 & 11.049 & 0.02 \\
\hline \multicolumn{5}{|l|}{ Healthcare provider characteristics } \\
\hline \multicolumn{5}{|c|}{ Length of time providing information (minutes) } \\
\hline$\geq 5$ & 1 (Ref) & & & \\
\hline$<5$ & 0.374 & 0.150 & 1.931 & 0.14 \\
\hline \multicolumn{5}{|l|}{ Length of time working (years) } \\
\hline$<20$ & 1 (Ref) & & & \\
\hline$\geq 20$ & 0.726 & 0.239 & 2.209 & 0.57 \\
\hline \multicolumn{5}{|l|}{ Employment status } \\
\hline Government employee & 1 (Ref) & & & \\
\hline Non government employee & 2.446 & 0.461 & 12.962 & 0.29 \\
\hline \multicolumn{5}{|l|}{ Age (years) } \\
\hline$\leq 35$ & 1 (Ref) & & & \\
\hline$>35$ & 1.342 & 0.378 & 4.766 & 0.65 \\
\hline \multicolumn{5}{|l|}{ Husband's supports } \\
\hline \multicolumn{5}{|c|}{ Accompanying to the follow-up examinations } \\
\hline No & 1 (Ref) & & & \\
\hline Yes & 1.79 & 0.646 & 5.199 & 0.22 \\
\hline \multicolumn{5}{|l|}{ Asking about cryotherapy results } \\
\hline No & 1 (Ref) & & & \\
\hline Yes & 1.669 & 0.546 & 5.099 & 0.37 \\
\hline \multicolumn{5}{|l|}{ Reminding wife to take medicine } \\
\hline No & 1 (Ref) & & & \\
\hline Yes & 0.682 & 0.221 & 2.108 & 0.51 \\
\hline \multicolumn{5}{|c|}{ Asking about wife's health condition } \\
\hline No & 1 (Ref) & & & \\
\hline Yes & 6.658 & 1.794 & 24.702 & $<0.01$ \\
\hline \multicolumn{5}{|l|}{ Providing transportation money } \\
\hline No & 1 (Ref) & & & \\
\hline Yes & 1.552 & 0.504 & 4.598 & 0.46 \\
\hline \multicolumn{5}{|c|}{$\begin{array}{l}\text { Providing money for food supplements and } \\
\text { vitamins }\end{array}$} \\
\hline No & 1 (Ref) & & & \\
\hline Yes & 1.852 & 0.804 & 4.698 & 0.22 \\
\hline \multicolumn{5}{|l|}{ Smoking } \\
\hline No & 1 (Ref) & & & \\
\hline Yes & 0.886 & 0.331 & 2.374 & 0.06 \\
\hline \multicolumn{5}{|l|}{ Asking for sex } \\
\hline Yes & 1 (Ref) & & & \\
\hline No & 4.151 & 1.491 & 11.556 & $<0.01$ \\
\hline
\end{tabular}


not work, husband support in terms of promoting maternal health and abstaining from sex for 4 weeks after cryotherapy. Mothers who do not work are more compliant than those who work, which is likely due to time availability of the mothers. Respondents who did not have on schedule three follow-up examinations were due to forgetfulness, being busy and lack of transport options. As many as $22.0 \%$ of respondents who did not come to the second follow-up examination and $10.5 \%$ at the third follow-up revealed the reasons for being busy working.

The second factor found to be related to maternal compliance with the four post-cryotherapy requirements was husband's support. In our study, husband's support consisted of three components namely social support, psychological support, environmental support. In the multivariate analysis, only two components were found to be associated with maternal compliance, namely asking about the health condition of the mother (psychological support) and not asking for sex for four weeks (environmental support). In our study, the proportion of respondents who said her husband asked for sex after cryotherapy is $56.3 \%$ and those who had sex amounted to $32.4 \%$. Thus in this case there is the role of the wife to reject having sex with their husband. Other studies show that $62.0 \%$ of husbands did not allow mothers to have cryotherapy because of the requirement not to have sex for 3-4 weeks after cryotherapy. ${ }^{15,16}$

In the multivariate analysis, nine other indicators of husband support were not found to be associated with maternal compliance after cryotherapy but were found to be associated in the bivariate analysis. These variables are accompanying wife to the follow-up examinations, asking about the results of cryotherapy, giving money for transportation, reminding to take medicine and not smoking. The other four variables were not found to be associated with the mother's compliance, which were helping daily household activities, giving money for food supplements and vitamins, being aware about maternal participation in cryotherapy and reminding her to take medicine. A similar study in Temanggung, Central Java, shows that the proportion of follow-up tests after cryotherapy in mothers when accompanied by their husbands was higher than those unaccompanied, with a proportion ratio (PR) of 1.19. ${ }^{17}$ Studies in other countries, which were in Myanmar and Mexico, show that husband support increased compliance of the mothers in post cryotherapy care. ${ }^{18,19}$

Husband's social and environmental support are influential on the mother's compliance with the four post-cryotherapy requirements. Although not in the same context, another study shows that husband's support was found to play a role in the success of health programs such as VIA in Africa. It was found that 45 out of 243 women who tested positive for VIA refused cryotherapy because they did not get permission from their partner or husband. ${ }^{20}$ In a qualitative study in Malawi, it was also found that husband involvement affected the success of VIA screening and cryotherapy. ${ }^{21} \mathrm{~A}$ study in Yogyakarta also shows that the external factor which predominantly related to VIA/pap smear examination was support from husband. ${ }^{22}$

In our study, maternal compliance with the recommended antibiotics use was $62.3 \%$. This compliance is related to husband's support, especially in terms of reminding mothers to take the prescribed medicine. Previous studies related to adherence to taking post-cryotherapy medication have not been found but it was shown that husband's support would increase maternal compliance in following clinical guidelines or doctor's instructions. ${ }^{18}$ Other studies related to adherence in taking long-term medications such as anti-tuberculosis regimens in North Tapanuli, North Sumatra show that family support including that of the husband is related to compliance of respondents taking medication $(\mathrm{p}<0.01){ }^{23,24}$ The role of husband support was also reported to be successful in increasing maternal compliance in the standby husband program (called program suami siaga) where the husband is motivated to be ready to accompany and transport his wife whenever needed. ${ }^{25}$ Another study also shows that the husband's knowledge greatly influences the husband's decision to support cancer treatment of his partner. ${ }^{26}$ This can also be extended to the VIA and cryotherapy programs to increase the scope and success of the program by increasing the husband's support for his wife, both social and and environmental support.

The limitation of this study is the possibility of recall bias due to some information collected which related to the events in the past. This study was conducted in a limited area so that the results cannot be generalized to a broader context.

\section{CONCLUSION}

Maternal compliance in carrying out the four requirements after cryotherapy remains low, especially abstaining from sex for four weeks after cryotherapy, on schedule follow-up examinations and compliance with the recommended antibiotic use. Mothers who do not work and husbands support in the form of asking about their wife's health condition and not asking for sex were associated with maternal compliance after cryotherapy. 


\section{ACKNOWLEDGEMENTS}

We would like to thank the heads of all PHCs selected as the locations for this study and all respondents who have participated in this study.

\section{REFERENCES}

1. Bray F, Ferlay J, Soerjomataram I, Siegel RL, Torre LA, Jemal A. Global cancer statistics 2018: GLOBOCAN estimates of incidence and mortality worldwide for 36 cancers in 185 countries. CA: A Cancer Journal for Clinicians. 2018; 68(6): 394-424.

2. National Comprehensive Cancer Network. NCCN guidelines: Cervical cancer. 2019

3. World Health Organization. Cancer country profiles. Geneva: WHO; 2014

4. Indonesia Ministry of Health. Profil Kesehatan Indonesia [Indonesia Health Profile]. Jakarta: Indonesia Ministry of Health; 2017.

5. Bali Province Health Office. Profil Kesehatan Provinsi Bali 2016 [Bali Province Health Profile]. Denpasar: Bali Province Health Office; 2017.

6. Cervical Cancer Action Coalition. New options for cervical cancer screening and treatment in low-resource settings. 2007

7. Iskandar TM. Pengelolaan lesi prakanker serviks [Management of cervical precancerous lesions]. Indonesian Journal of Cancer. 2009;3(3):97-102.

8. Lestari L, Purwoto G, Nuranna L. Efficacy and safety of cryotherapy in "See and Treat" Program in Jakarta primary health centre. Indonesian Journal of Obstetrics and Gynecology. 2016;4(4):227-233.

9. Jahic M, Jahic E, Mulavdic M, Hadzimehmedovic A. Difference between cryotherapy and follow up low grade squamous lesion of cervix uteri. Medical Archives. 2017;71(4):280-283.

10. Sankaranarayanan R, Rajkumar R, Esmy PO, Fayette JM, Shanthakumary S, Frappart L, et al. Effectiveness, safety and acceptability of 'see and treat' with cryotherapy by nurses in a cervical screening study in India. British Journal of Cancer. 2007; 96(5):738-743.

11. Indonesia Ministry of Health. Pedoman teknis pengendalian kanker payudara \& kanker leher rahim [Technical guidelines of breast and cervical cancers management]. Jakarta: Indonesia Ministry of Health; 2013.

12. Tabanan District Health Office. Protap pemeriksaan IVA dalam penanggulangan kanker serviks di Kabupaten Tabanan [Guidelines of the VIA examination in cervical cancer management in Tabanan District]. Tabanan: Tabanan District Health Office; 2011.

13. Tabanan District Health Office. Profil Dinas Kesehatan Kabupaten Tabanan [Profile of Tabanan District Health Office]. Tabanan: Tabanan District Health Office; 2016.

14. Dagun MS. Psikologi Keluarga [Family Psychology]. Jakarta: Rineka Cipta; 2002.

15. Coffey PS, Bingham A, Winkler JL, Bishop A, Sellors JW, Lagos G, et al. Cryotherapy treatment for cervical intraepithelial neoplasia: women's experiences in Peru. Journal of Midwifery \& Women's Health. 2005;50(4):335-340.

16. Aprilia MD. Hubungan dukungan suami dengan pelaksanaan cryotherapy di Puskesmas Candiroto Kabupaten Temanggung (Skripsi) [The association between husband support and cryotherapy at the Candiroto Public Health Center, Temanggung District (Undergraduate thesis)]. Semarang: Ngudi Waluyo University; 2017.
17. Napitupulu D, Hutajulu SH. Faktor-faktor yang mempengaruhi tindakan cryotherapy pada individu IVA positif di Kabupaten Temanggung (Tesis) [Factors influencing cryotherapy among VIA positive individuals in Temanggung District (Thesis)]. Yogyakarta: Gadjah Mada University; 2017.

18. Thida M, Thin KM, Thein ZM, Sein YY, Nyunt T, Sanda. Effectiveness, safety and acceptability of the method of visual inspection with acetic acid (VIA) and cryotherapy based single-visit approach to cervical cancer prevention (CCP) in Kungyangon Township, Yangon Region, Myanmar. Burma Medical Journal. 2015;57(3):48-56.

19. Bingham A, Bishop A, Coffey P, Winkler J, Bradley J, Dzuba I, et al. Factors affecting utilization of cervical cancer prevention services in low-resource settings. Salud Publica de Mexico. 2003;45(Suppl 3):S408-S416.

20. WHO. Prevention of cervical cancer through screening using visual inspection with acetic acid (VIA) and treatment with cryotherapy: A demonstration project in six African countries (Malawi, Madagascar, Nigeria, Uganda, the United Republic of Tanzania, and Zambia). Geneva: WHO; 2012

21. Munthali AC, Ngwira BM, Taulo F. Exploring barriers to the delivery of cervical cancer screening and early treatment services in Malawi: some views from service providers. Patient Preference and Adherence. 2015;9: 501-508.

22. Pertiwi NDE. Faktor-faktor yang berhubungan dengan kunjungan pemeriksaan IVA/Pap smear pada ibu-ibu PKK di Dusun Tajem Depok Sleman (Skripsi) [Factors associated with VIA/Pap smear examinations among mothers in Tajem Village, Depok Sub-district, Sleman District (Undergraduate thesis)]. Yogyakarta: Aisyiyah Health Institute; 2015.

23. Loriana R, Parellangi, Siswoyo. Efek konseling terhadap pengetahuan, sikap dan kepatuhan berobat penderita tuberkulosis paru [Effect of counseling on knowledge, attitude and patients' compliance with pulmonary tuberculosis treatment]. Jurnal Husada Mahakam. 2013;3(6):263-318.

24. Siregar I. Hubungan antara dukungan keluarga dengan kepatuhan minum obat pada penderita tuberkulosis paru di Puskesmas Pangaribuan, Puskesmas Situmeang Habinsaran dan Puskesmas Hutabaginda di Kabupaten Tapanuli Utara (Tesis) [The association between family support and treatment compliance among pulmonary tuberculosis patients at Pangaribuan, Situmeang Habinsaran and Hutabaginda Public Health Centers in North Tapanuli District (Thesis)]. Medan: North Sumatera Univesity; 2019.

25. Evayanti Y. Hubungan pengetahuan ibu dan dukungan suami pada ibu hamil terhadap keteraturan kunjungan antenatal care (ANC) di Puskesmas Wates Lampung Tengah Tahun 2014 [The association between mother's knowledge and husband's support among pregnant mothers with antenatal care visit at Wates Public Health Center, Center Lampung, Year 2014]. Jurnal Kebidanan. 2015;1(2), 81-90.

26. Ragan KR, Lunsford NB, Smith JL, Saraiya M, Aketch M. Perspectives of screening冈eligible women and male partners on benefits of and barriers to treatment for precancerous lesions and cervical cancer in Kenya. Oncologist. 2018;23(1): 35-43

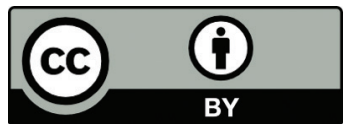

This work is licensed under a Creative Commons Attribution 